IMECE2011-63660

\title{
COMPARATIVE STUDY AMONG HYBRID GROUND SOURCE HEAT PUMP SYSTEM, COMPLETE GROUND SOURCE HEAT PUMP AND CONVENTIONAL HVAC SYSTEM
}

\author{
Jiang Zhu, Graduate Research Assistant \\ Mechanical and energy engineering \\ University of North Texas \\ Denton, TX, USA
}

\begin{abstract}
In this paper, a hotel with hybrid geothermal heat pump system (HyGSHP) in the Pensacola is selected and simulated by the transient simulation software package TRNSYS [1]. To verify the simulation results, the validations are conducted by using the monthly average entering water temperature, monthly facility consumption data, and etc. And three types of HVAC systems are compared based on the same building model and HVAC system capacity. The results are presented to show the advantages and disadvantages of HyGSHP compared with the other two systems in terms of energy consumptions, life cycle cost analysis.
\end{abstract}

Key words: HyGSHP; TRNSYS; SIMULATION

\section{NOMENCLATURE}

$\begin{array}{ll}\text { ASHP } & \text { Air source heat Pump } \\ \text { DHW } & \text { Domestic hot water } \\ \text { EWT } & \text { Entering water temperature } \\ \text { GSHP } & \text { Ground source heat pump } \\ \text { HyGSHP } & \text { Hybrid ground source heat pump } \\ \text { SPA } & \text { Hot water spa and swimming pool } \\ \text { OA } & \text { Outside air }\end{array}$

\section{INTRODUCTION}

Hybrid geothermal heat pump system has become more and more attractive in the cooling or heating dominated location, due to comparative economic benefit and loop field land area saving. Compared with the complete ground source heat pump (GSHP), HyGSHP integrates the supplemental heat rejection or extraction systems with the ground source heat exchanger to balance the cooling and heating demand from ground in its prolonged cooling or heating location. This situation is relative unique compared to northern regions where the balanced annual cooling and heating load requirements exist (i.e., the ground heat charging and discharging loads are about the same.). And another important feature of HyGSHP is saving the field area because of low capacity size of ground heat exchanger size requirement.

\author{
Yong Tao, Chair, Professor, \\ Mechanical and energy engineering \\ University of North Texas \\ Denton, TX, USA
}

However, there is little information and general guideline on the design of the HyGSHP system. Furthermore, several variables of HyGSHP, such as cooling tower size, geothermal heat exchanger (GHX) size, connection method and control strategies, make the HyGSHP design and configuration much more complicated than the complete ground heat exchanger. Therefore more research and experiments are needed to do in order to create a guideline for HyGSHP design which can be used in various locations and different applications, such as residential buildings, commercial building, institutional buildings, and etc.

A number of recent reports and research papers have been published that deal with the design of HyGSHP and operation experience.

The ASHRAE Ground Source Heat pump Engineering Manual [2] discusses the advantages of hybrid ground source heat pump applications based on the economical benefit and land area limitation compared with complete ground source heat pump system.

Kavanaugh [3] introduces a revised and extended procedures based on existing design ones as recommended in ASHRAE.

Phetteplace and Sullivan [4] present a performance case of a $24,000 \mathrm{ft}^{2}\left(2,230 \mathrm{~m}^{2}\right)$ military base administration building, located in Fort Polk, LA that uses a HyGSHP system.

Singh and Foster [5] reports the first cost savings that results from using a HyGSHP compared to the conventional closed loop source heat pump system.

Gilbreath [6] presents a more detailed study on the HyGSHP system in Paragon Center, and attempts to establish methods for monitoring system according to the measurement of energy demand, energy consumption, and loop temperatures.

Yavuzturk and Spitler [7] present a comparative study to investigate the several control strategies by using a short time step simulation model.

Al Barfield [8] reports a Hybrid geothermal heat pump system design and measurement for a beachfront hotel. And the building mentioned in this report is selected as the research case study for HyGSHP in this paper. 
Scott P. Hackel and Thornton [9] present a simulation study on the HyGSHP based on a sample building with assumed parameters in order to create a HyGSHP model and optimizer to help practicing engineer to appropriately size the ground heat exchanger, supplemental heat rejecter or extractor, in cooling or heating dominated climate.

In this paper, a HyGSHP case modeling is presented for the further understanding of HyGSHP. And a hotel located in hot-humid climate Pensacola uses the HyGSHP which combines GHX with closed circuit cooling tower as the additional heat rejection. The existing system in the hotel is simulated using TRNSYS with the building model created by GOOGLE SKETCHUP [10]. Then the HyGSHP system is compared with the complete GSHP and air source heat pump system based on the energy consumption and life cycle cost analysis. The building and system models are introduced in the rest of the paper.

\section{BUILDING MODEL}

The hotel is located on a barrier island on the Florida Gulf coast, and there are 117 room facilities with large public parking area, meeting room, a large dining room and a limited breakfast area which totaled $80,145 \mathrm{ft}^{2}$, and the hotel includes some amenities such as one health club, two large outdoor heated pools, one outdoor heated spa and a large, shallow children's pool [8].

Based on the blueprint, the building model is created by the drawing software GOOGLE SKETCHUP, a free 3D modeling program. Figure 1 shows the comparative view of the real building and the simulation building model. And the following assumption is made with the simulation building model:

1. The building is divided into 9 thermal zones, which each heat pump units served.

2. Building materials (walls, roofs and windows) imitate the real case, lighting equipment schedule is assumed.

3 . The total number of occupants is set as 300 , and lighting and equipment load is set as $1 \mathrm{~W} / \mathrm{ft}^{2}$ and $1.1 \mathrm{~W} / \mathrm{ft}^{2}$ based on the Asharae standard 90.1.

4. Infiltration is set as $1 \mathrm{1} / \mathrm{h}$ based on the beachfront location and the fresh air require in the real case.

5. Thermostat setpoint of $70^{\circ} \mathrm{F}$ heating and $73^{\circ} \mathrm{F}$ cooling during all day is used in all zones.

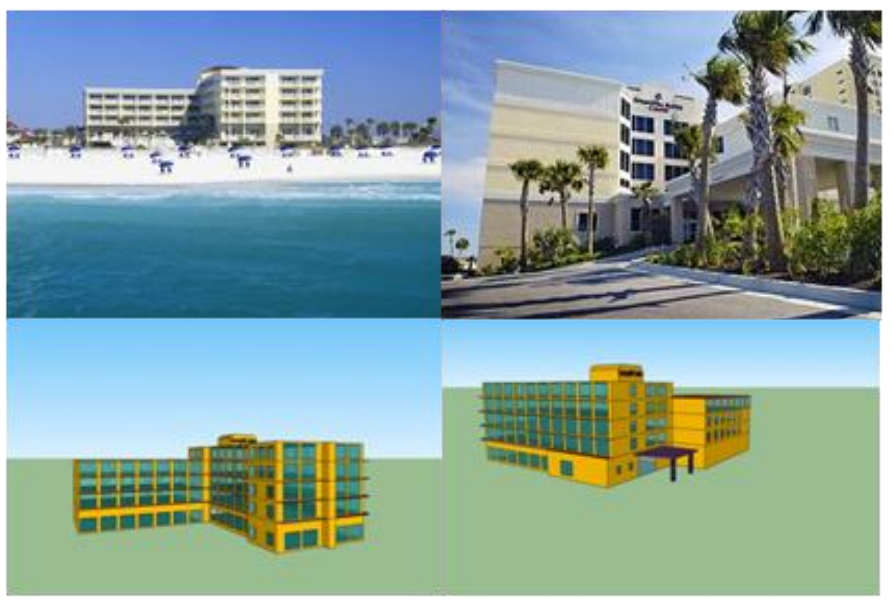

Figure 1. Building model by GOOGLE SKTCHUP

\section{SYSTEM MODEL}

The hotel includes 117 room unitary heat pump units (180 tons in total), two $100 \%$ outside air rooftop air conditioner, three $64 \mathrm{KBtu} / \mathrm{h}$ water-to-water heat pumps for domestic heat water and two $390 \mathrm{KBtu} / \mathrm{h}$ water-to-water heat pump for swimming pool and spa heating equipment.

Because of the limited installation field area available for the geothermal heat exchanger loop, the designer of HYGSHP system selected a 150 tons closed-loop evaporative fluid cooler to parallel the ground-coupled loop field which owns 98 boreholes with 200 depths and 1" U-tube to compose the HYGSHP system.

In order to simulate the complete system, the transient simulation software package is employed to simulate it with the short time step during one year period ( 5 minutes is set as the simulation time step), and the hourly typical meteorological year for the Pensacola is used, then the HVAC system worked with the well calibrated building model can predict the enter water temperature, the system profile and the building energy consumption, etc. And the simulation system below is trying to simulate the building model and all the heat rejecting and extraction system like water to water heat pump, air source heat pump, cooling tower as real system. However, several simplifications are made to make the simulation realizable and computationally efficient.

1. The five story building is divided into 9 zones which are served with one large heat pump unit, which is kept as the same capacities.

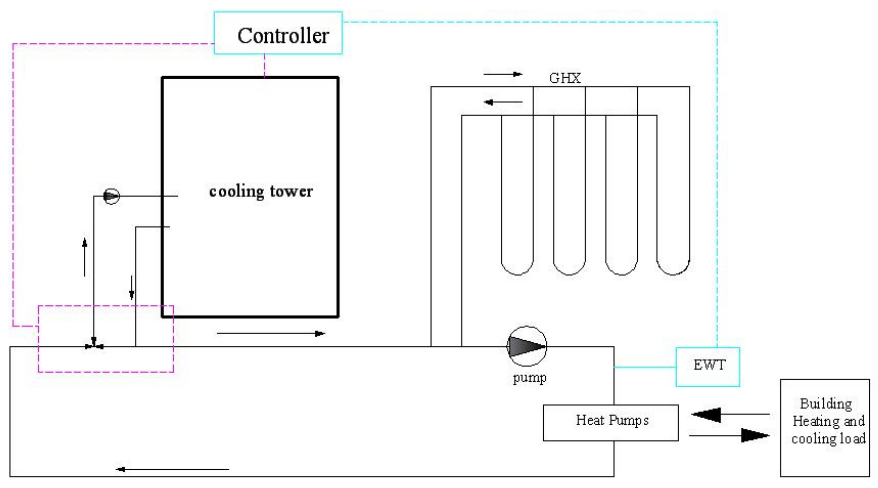
Figure 2. Schematic diagram the existing HyGSHP
configuration

2. in order to improve the computation efficiency.Ice machine is not included because of its relative negligible energy consumption.

3. The ground conductivity, diffusivity, temperature are input based on the reasonable assumptions. (Listed in the appendix).

The diagram of HyGSHP in the hotel is shown in Fig. 2, the cooling tower is activated when enter water temperature is over $84{ }^{\circ} \mathrm{F}$. The components such as closed circuit cooling tower, vertical ground heat exchanger, water to air heat pump are included in the TRNSYS model.

\section{VALIDATIONS}


In order to verify the simulation model and building model, the validation process is important to make the results convincing and trustworthy.

In this study, the measure data during the first year of hotel open to public is used for validation of the first year of simulation to verify the building model and system model. And all the measure data is gathered from Al Barfield's report [8] which monitored the average return water temperature, domestic hot water and heating spa consumption and total building consumption.

The simulation results and the measured data are compared comprehensively in the Fig. 3, Fig. 4, Fig. 5, Fig. 6, Fig. 7 and Fig. 8 based on the first year of system operation. According to Fig. 3, the average entering water temperature from the simulation is well matched with measured data. And the specific energy consumption item are compared respectively illustrated in the Fig. 4, Fig. 5 and Fig. 6 which shows the validation among cooling tower consumption, DHW\&SPA heating consumption, and the total building calendar energy consumption.

According to these validations, there is a little difference between the simulation data and measured data. Three main reasons are listed as bellowed:

1. The typical meteorological year weather data is different from the real weather data; it causes the errors between the simulation and real operation.

2. For the validation with DHW and SPA heating, it is difficult to be consistent with the actual operation and is hard to simulate the usage with accurate water draw and operation schedule.

3. The assumed lighting and equipment consumption is not accurate to predict the real energy consumption and heat gain.

Furthermore, Figure 7 shows the composition of the annual total building consumption, the simulation result have less than $2 \%$ of difference with the statistic map from utility company (shown in Fig. 8)

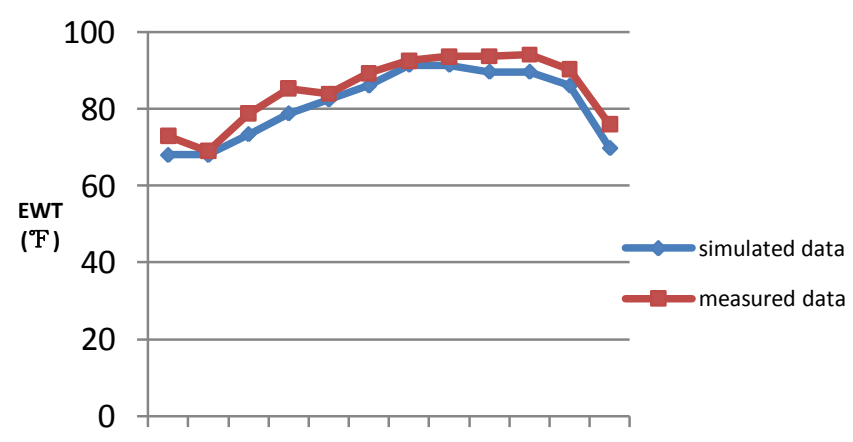

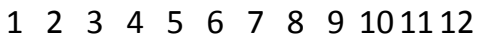

Month

Figure 3. Average enter water temperature

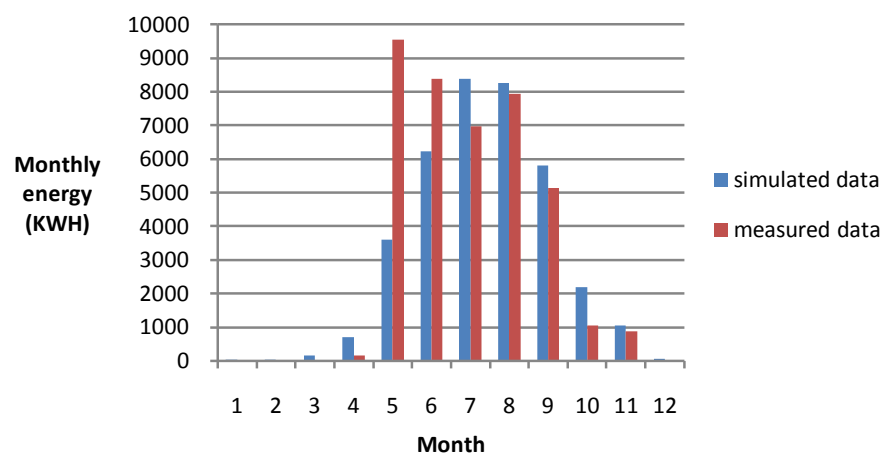

Figure 4. Cooling tower consumption

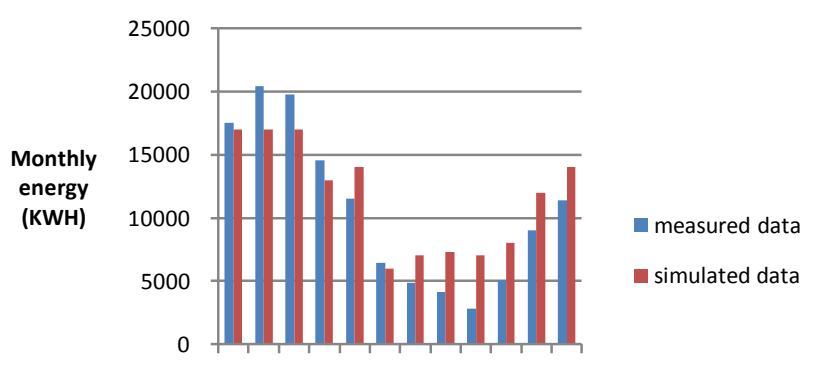

123456789101112

Month

Figure 5. DHW and SPA heating consumption

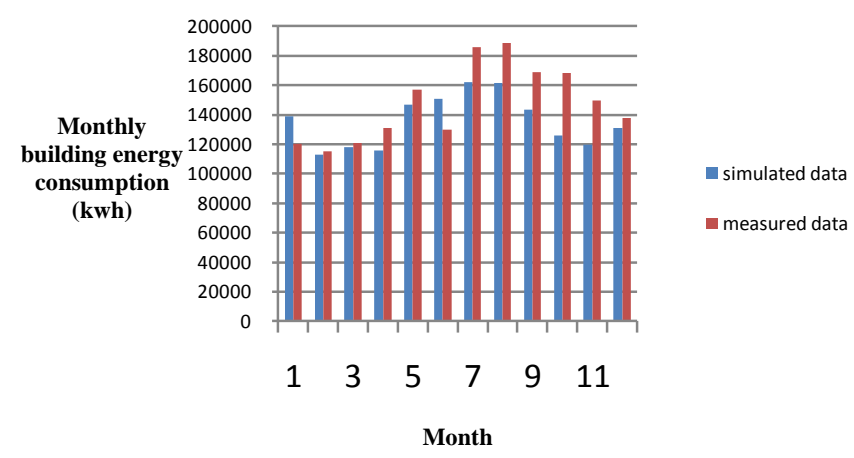

Figure 6. Building calendar energy consumption

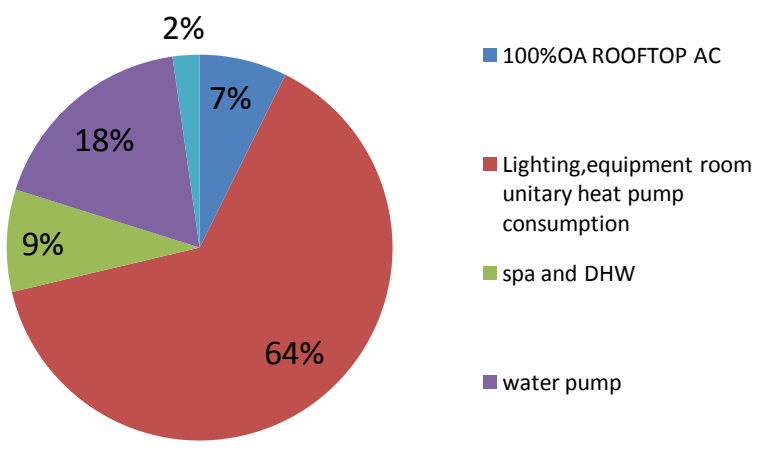

Figure 7. The energy summary from simulation 


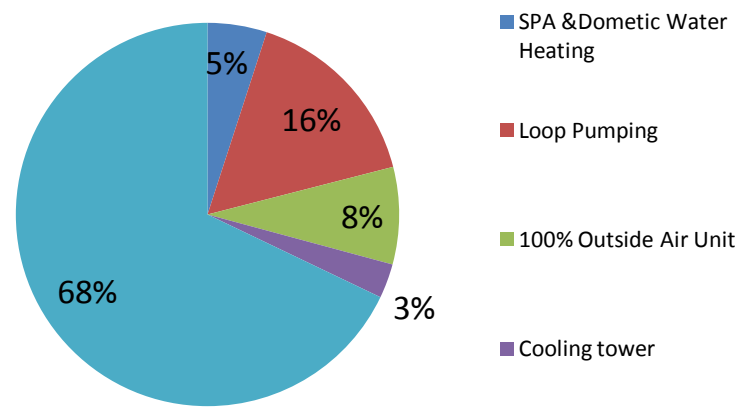

Figure 8. The energy summary from utility company

According to the well comparison, we can say the modeling results are trustworthy and reasonable. In the next section, the calibrated building model installed with different HVAC system is simulated and the energy comparison results are presented.

\section{RESULTS AND DISCUSSION}

After the validations above, the validated building model and system model are set up well. In order to reseach the advantage and disadvange of HyGSHP compared with other type of HVAC system, the building model with the alternative complete GSHP and ASHP system is simulated. And Fig. 9 and Fig. 10 (screenshot from TRNSYS plotter) shows the ground temperature (red line) and subhourly exiting water temperature of GHX for the validated HyGSHP system. Then the HyGSHP system is substitued by the complete ground source heat pump system which contain 245 boreholes with $200 \mathrm{ft}$ depth with total estimated 250 tons capacity.

From Fig. 9 and Fig. 10, with the same HVAC system capacity, the exiting water temperature of complete GSHP has lower fluctuation and is controlled more effeciently than the exiting fluid temperature of HyGSHP. The reasons are as follow:

First of all, these two HVAC systems, the spacing of boreholes and the inlet mass flow rate of GHX is set as the equal for the HyGSHP and GSHP.

And according to the heat convection Eq. (1):

$$
q=h A\left(T_{\text {surface }}-T_{\text {fluid }}\right)
$$

Where,

q, energy transfer rate

$\mathrm{h}$, convection heat-transfer coefficient

$\mathrm{T}_{\text {surface }}$, surface temperature of U-TUBE

A, surface area of U-TUBE

Because the complete ground heat exchanger with lengthened ground heat exchange length has the larger surface area of U-TUBE of ground heat exchanger than surface area of U-TUBE of the HyGSHP, more heat is transferred from fluid to the ground in the GSHP that the heat transferred in the HyGSHP.

Therefore, according to the Eq. 2, with the same mass flow rate and thermal conductivity for GSHP and HyGSHP, complete ground source heat pump discharges more heat into ground; therefore, the outlet temperature $\mathrm{T}_{\text {outlet }}$ is lower than than for HyGSHP when the fuild goes through the ground heat exchanger ( see Fig. 9 and Fig. 10). This may explain why the case of HyGSHP resulted in a higher ground temperature.

$$
q=\dot{m} c\left(T_{\text {outlet }}-T_{\text {inlet }}\right)
$$

Where,

$\dot{\mathrm{m}}$, mass flow rate

$\mathrm{C}$, thermal conductivity
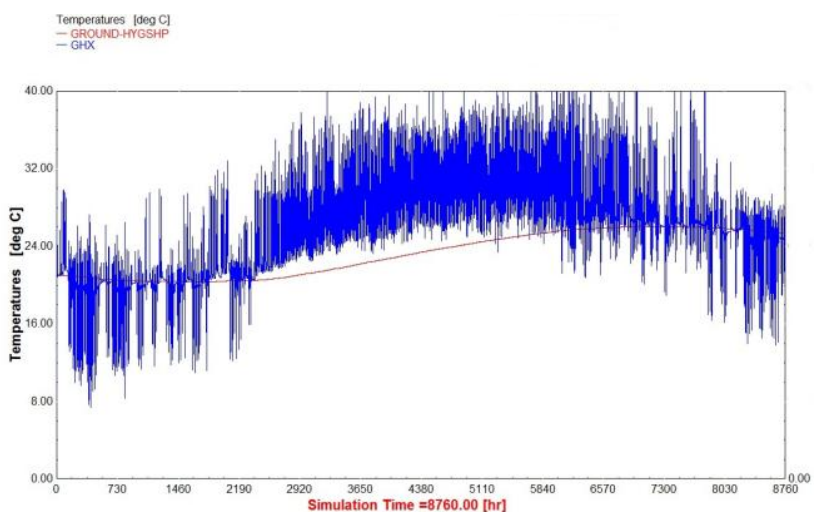

Figure 9. Plot of hourly ground temperature and EWT for HyGHSP

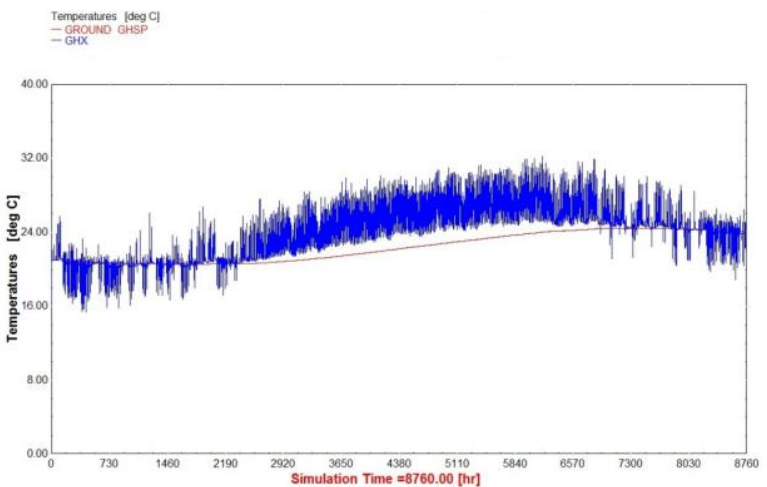

Figure 10. Plot of hourly ground temperature and EWT for GHSP

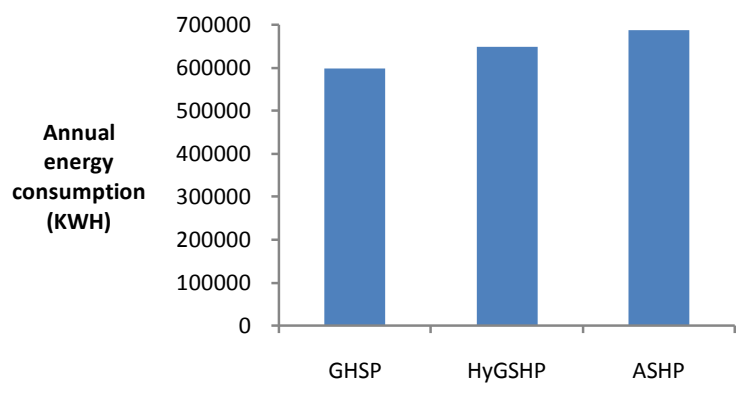

Figure 11. Comparison of annual system energy consumption among three types of system

(Note: the total consumption include the main loop pumping water source heat pump (or air source heat pump) 
consumption, cooling tower and DHW \& SPA heating consumption).

The life cycle analysis is conducted in order to see the economic feature of these three system, the following assumptions are made:

1. $\$ 10.00$ per foot at borehole is used for the calculation of the cost of the ground heat exchanger (Kavanaugh [3] uses the value the $\$ 6.00$ per foot, the inflation is considered in the study).

2. Cooling tower cost is about 17,000 from the manufacturing company.

3. Air source heat pump and water source heat pump is calculated based on $\$ 1000 /$ ton and $\$ 983 /$ ton respectively [11]

4. The cost of electricity is assumed to be $\$ 0.102$ per $\mathrm{kWh}$.(The information regarding the electricity prices were acquired from U.S. Energy Information Administration website)

5. Tax credit program is consider in the analysis, which offers tax credit up to a $30 \%$ of initial cost without cap. Also, in some parts southern States, a \$300/ton rebate program is offered by energy companies.

6. According to a few studies on this subject, the maintenance costs were used as annual maintenance costs and estimated as $\$ 0.027 / \mathrm{ft}^{2}$ per year for the GSHP system tonnage. For maintenance cost of conventional systems, RS Means Facility Maintenance Cost Data was used. The cost was $\$ 0.102 / \mathrm{ft}^{2}$ per year.[12]

The equation to calculate the life cycle cost in the paper is summarized as Eq. (3)

Life cycle cost $=$ Initial cost after rebate + Energy cost of 20 years $+O M \& R$ of 20 years

Where,

Initial cost after rebate $=$ ground heat exchanger cost + heat pumps cost + cooling tower cost - credit

Credit $=30 \% \times($ ground heat exchanger cost + heat pump cost $)$

OM\&R: operation maintenance and repair cost

Compared with conventional air source heat pump system:

Payback period for GSHP or HyGSHP = (initial cost difference between GSHP or HyGSHP and ASHP) / (the annual net savings)

Table 1 summary of 20 years Life Cycle Analysis

\begin{tabular}{|l|l|l|l|}
\hline & HyGSHP & GSHP & ASHP \\
\hline
\end{tabular}

\begin{tabular}{|l|l|l|l|}
\hline $\begin{array}{l}\text { System } \\
\text { description }\end{array}$ & $\begin{array}{l}\text { 80,145 } \mathrm{ft}^{3} \\
\text { building } \\
\text { area } \\
98 @ 200 \mathrm{ft} \\
\mathrm{GHX}\end{array}$ & $\begin{array}{l}80,145 \mathrm{ft}^{3} \\
\text { building } \\
\text { area } \\
\text { 245@ 200ft } \\
\mathrm{GHX}\end{array}$ & $\begin{array}{l}80,145 \mathrm{ft}^{3} \\
\text { building } \\
\text { area }\end{array}$ \\
\hline $\begin{array}{l}\text { Land area } \\
\text { requirement } \\
\text { for system }\end{array}$ & $40,000 \mathrm{ft}^{2}$ & $100,000 \mathrm{ft}^{2}$ & --- \\
\hline $\begin{array}{l}\text { Cost of } \\
\text { Ground heat } \\
\text { exchanger }\end{array}$ & $\$ 196,000$ & $\$ 490,000$ & --- \\
\hline $\begin{array}{l}\text { Heat pump } \\
\text { (water } \\
\text { source or air } \\
\text { source) }\end{array}$ & $\$ 294,900$ & $\$ 294,900$ & $\$ 315,000$ \\
\hline $\begin{array}{l}\text { Cooling } \\
\text { tower cost }\end{array}$ & $\$ 17,000$ & -- & -- \\
\hline $\begin{array}{l}\text { Credit } \\
\text { after rebate }\end{array}$ & $\$ 147,270$ & $\$ 235,470$ & --- \\
\hline $\begin{array}{l}\text { 20 years } \\
\text { maintenance } \\
\text { cost }\end{array}$ & $\$ 50,000$ & $\$ 43,278$ & $\$ 163,490$ \\
\hline $\begin{array}{l}20 \text { years of } \\
\text { electricity } \\
\text { cost }\end{array}$ & $\$ 1,389,241$ & $\$ 1,278,934$ & $\$ 1,473,336$ \\
\hline $\begin{array}{l}\text { Life cycle } \\
\text { cost }\end{array}$ & $\$ 1,782,871$ & $\$ 1,871,642$ & $\$ 1,951,826$ \\
\hline $\begin{array}{l}\text { Payback } \\
\text { period }\end{array}$ & 2.9 years & 14 years & --- \\
\hline
\end{tabular}

Note: 1. the land cost is not included in the initial cost. It assumes the hotel already owns this property.

2. Electric consumption is based on the first years running (actually the consumption will increase a little after long time operation because of increase of the ground temperature)

According to the results in the Table 1, HyGSHP has the economic benefit compared with other two types of system. Even if the complete ground source heat pump system will save a significant amount of energy, it still cannot beat HyGSHP system because of large initial cost and land area utilization. Both innovated HyGSHP and GSHP system have the economic advantage compared with the conventional air source heat pump.

\section{CONCLUSIONS AND FUTURE WORK}

In the chapter, three type HVAC systems are studied and simulated based on well validated building model. The designers of the HVAC system designed the hybrid ground source heat pump system due to the land area limitation for the complete ground source heat pump system. Nevertheless, in order to make a comparison between the performance of hybrid ground source heat pump and the complete ground source heat pump, the enough land area is assumed for the complete ground source heat pump. 
In order to avoid the degradation of ground source heat pump in the hot-humid climate due to the imbalance between heating load and cooling load of the building, two enhanced systems, complete ground source heat pump with lengthened ground heat exchanger length and the hybrid source heat pump are the two main solutions. According to the comparative simulation study above, the complete ground source heat pump system which increases the total borehole length has the better energy performance than the existing hybrid system. However, the large initial cost and large land area limitation for the building make the system as the second option, and the payback period is too long compared with HyGSHP.

Hybrid ground source heat pump significantly decreases the initial cost and the requirement of land area and maintains relatively high energy performance. According to the 20 years life cycle analysis, the hybrid system owns the economical advantage compared with other two systems in the hot-humid climate. But for the longer time running, complete ground source heat pump will overtake the hybrid system due to the better energy performance.

\section{ACKNOWLEDGMENTS}

The findings in this paper are made possible by the financial support from US Department of Energy Geothermal Program under the Award No. DE-EE0002802, which is greatly appreciated.

\section{REFERENCES}

[1] SEL. 2009. TRNSYS Manual, a Transient Simulation Program. Madison: Solar Engineering Laboratory, University of Wisconsin.

[2] ASHRAE. 1995. Commercial/Institutional Ground Source Heat Pumps Engineering Manual. Atlanta: American Society of Heating, Refrigerating and Air-Conditioning Engineers, Inc. [3] Kavanaugh, S. P., 1998. A Design Method for Hybrid Ground-Source Heat Pumps. ASHRAE Transactions 104(2).

[4] Phetteplace, G. and W. Sullivan. 1998. Perormance of a Hybrid GCHP System. ASHRAE Transaction 104(1).

[5] Singh, J. B., G. Foster. 1998. Advantages of Using the Hybrid Geothermal Option. The Second Stockton International Geothermal Conference. The Richard Stockton College of New Jersey.

[6] Gilbreath, C. S. 1996. Hybrid Ground Source Heat Pump Systems for Commercial Applications. M.S. Thesis. University of Alabama. Tuscaloosa, Alabama.

[7] Yavuzturk, C. 1999. Modeling of Vertical Ground Loop Heat Exchangers for Ground Source Heat Pump Systems. Ph.D. Thesis. Oklahoma State University. Stillwater, OK. [8] Al Barfield. Hybrid Geothermal Heat Pump Beachfront Hotel. ASHARE Journal, September, 2006

[9] Scott P. Hackel and Thornton. 2008. Development of Design Guidelines for Hybrid Ground-Coupled Heat Pump Systems. ASHRAE TRP-1384

[10] Google Inc. 2011. http://sketchup.google.com/intl/en/index.html (download available.)

[11] R.S. Means, Mechanical Cost Data, R.S. Means (2006). [12] R.S. Means, Facilities Maintenance and Repair Cost Data, R.S. Means (2002).
[13] Kersten, M. A., 1949. Thermal Properties of Soils. University of Minnesota Engineering. Experiment Station Bulletin No. 28.

[14] McQuay Inc. 2011. Geothermal Heat Pump Design Manual [online]. 


\section{APPENDIX A}

Table 2 input Summary for the Simulation Model

\begin{tabular}{|c|c|}
\hline Construction Details & Existing Building \\
\hline Total Conditioned Area & $81,752 \mathrm{ft}^{2}$ \\
\hline number of floors & 5 \\
\hline Ext_wall layer & $\begin{array}{l}\text { Gypsum broad 2" } \\
\text { Wall:Concrete block stucco 12", } \\
\text { Exterior insulation and finish }\end{array}$ \\
\hline Roof Layer & Insulation(R-19), 6”STUD \\
\hline Floor Construction & $0.08 \mathrm{~m}$ concrete on ground, Cork cover \\
\hline Percent Glazing Area & $50 \%$ \\
\hline Glazing U-Value & $\mathrm{U}-0.509 \mathrm{BTU} / \mathrm{hr} . \mathrm{ft}^{2} .{ }^{\circ} \mathrm{F}$ \\
\hline Plant Details & HyGSHP \\
\hline Ground heat exchanger & HyGSHP \\
\hline Borehole hole & $98 @ 200 \mathrm{ft}$ deep \\
\hline U TUBE & 1 inch \\
\hline Ground conductivity & 0.8378 BTU/hr.ft. ${ }^{\circ} \mathrm{F}[13]$ \\
\hline Fill conductivity & $0.6741 \mathrm{BTU} / \mathrm{hr} . \mathrm{ft} .{ }^{\circ} \mathrm{F}$ \\
\hline HVAC & $\begin{array}{l}180 \text { tons unitary heat pump \& } 70 \text { tons water to water heat pump } \\
50 \text { tons } 100 \% \text { roof top air conditioner } \\
150 \text { tons cooling tower }\end{array}$ \\
\hline Initial Ground water temperature & $70^{\circ} \mathrm{F}[14]$ \\
\hline Total System Airflow & Constant air flow \\
\hline Cooling Setpoint Daytime/nighttime & $73^{\circ} \mathrm{F}$ \\
\hline Heating Setpoint - Daytime/Nighttime & $71^{\circ} \mathrm{F}$ \\
\hline Air Source Heat Pump (ASHP) & ASHP \\
\hline Cooling Setpoint Daytime/nighttime & $73^{\circ} \mathrm{F}$ \\
\hline Heating Setpoint - Daytime/Nighttime & $71^{\circ} \mathrm{F}$ \\
\hline \multicolumn{2}{|l|}{ Internal Loads } \\
\hline Lighting Power Density & 1.0 (assumed) W/ft ${ }^{2}$ \\
\hline Lighting Controls & specified \\
\hline Equipment/Plug load Density & $1.1 \quad$ (assumed) $\mathrm{W} / \mathrm{ft}^{2}$ \\
\hline Occupancy Density & Max $=300$ \\
\hline Operating Schedules & Specified \\
\hline Infiltration & 1.0 \\
\hline Plant Details & GSHP \\
\hline Ground heat exchanger & GSHP \\
\hline Borehole hole & 245@ $200 \mathrm{ft}$ deep \\
\hline U TUBE & 1 inch \\
\hline Ground conductivity & 0.6741 BTU/hr.ft.F \\
\hline Fill conductivity & 0.8378 BTU/hr.ft.F \\
\hline
\end{tabular}

